
d'histoire

\title{
Building an industrial society: welfare capitalism in the 'city of factories', Sesto San Giovanni, Italy
}

\section{Valerio Varini}

To cite this article: Valerio Varini (2016): Building an industrial society: welfare capitalism in the 'city of factories', Sesto San Giovanni, Italy, European Review of History: Revue européenne d'histoire, DOI: 10.1080/13507486.2016.1154928

To link to this article: http://dx.doi.org/10.1080/13507486.2016.1154928

\section{Published online: 13 Apr 2016.}

\section{Submit your article to this journal $\llbracket$}

Џ Article views: 9

Q View related articles ๘

View Crossmark data ־ 


\title{
Building an industrial society: welfare capitalism in the 'city of factories', Sesto San Giovanni, Italy
}

\author{
Valerio Varini \\ Department of Economics, Management and Statistics, University of Milano-Bicocca, Milan, Italy
}

\begin{abstract}
The article retraces the steps which marked the transformation of Sesto San Giovanni to becoming one of the principal centres of Italian industry. The premises serve to better comprehend the case of Sesto San Giovanni. Its uniqueness lies, however, in being the outcome of action by a plurality of businesses which contributed to building the 'factory city'. From 1905, their choice of setting up their plants caused a sudden increase in the population, which was followed by an equally sharp increase in the demand for lodgings and social infrastructures. The employers were forced to invest in building, at first with the intention of rapidly housing the workers, and then to proceed with a more rational planning of specific villages for the workforce. In the decades between the wars, Sesto San Giovanni was provided with a wide range of services in the fields of health care, schooling and even leisure. These policies permitted the creation of solid, closeknit company communities, founded on the intense participation of the workforce in the functioning of production activities. The social network, however, held together principally on the basis of the recognition of mutual obligations and responsibilities, rather than on mere subordination to paternalistic domination.
\end{abstract}

\section{ARTICLE HISTORY}

Received 19 March 2015

Accepted 2 January 2016

\section{KEYWORDS}

Business history; welfare; enterprise; company town

Since the beginning of industrialisation, different types of relationships have developed between the workplace and worker communities. Some of these relationships came to be broadly termed 'company towns'. Their great variety has sparked much debate regarding how they might be defined. ${ }^{1}$

Bearing in mind such complexity, the present study focuses on the links between companies and their workers, in the hope of offering some answers to the following pressing questions: why did companies invest in social and welfare services for their workers and the surrounding community? What relationship existed between the providers of these services, i.e., the company, and the beneficiaries, i.e., the workers? ${ }^{2}$

This relationship can be ascribed purely to the subordinate role of the worker, as amply debated in the more well-established historiography ${ }^{3}$, especially with regard to cases of company towns in Italy. ${ }^{4}$ Alternatively, it may be considered in terms of more complex 
connections, with an emphasis on their mutual ties and shared ethical and religious values, as well as explicit productive ends, which could produce mutually co-operative behaviour as opposed to a conflictual relationship. ${ }^{5}$

The case analysed here is that of Sesto San Giovanni, one of the major districts of Italian industrialisation and one which is comparable in importance and duration to other industrial districts in Europe, such as Le Creusot in France ${ }^{6}$ or the Ruhr area in Germany. ${ }^{7}$ At the same time, it has a number of unique characteristics, as its development was the result of several companies, and also allows for a deep analysis regarding the creation of a wide and differentiated company welfare system. The large number of companies involved produced an open environment in which workers were not dependent on one single employer, a situation which led to increasing attention to welfare and social services on the part of employers.

This study will begin by attempting to define the notions of paternalism and mutual interest. A brief digression will focus on company towns, highlighting not only the variety of forms that they took but also the importance of the case of Sesto San Giovanni itself ${ }^{8}$ followed by a brief description of welfare communities in Italy in the 1930s, highlighting how they became a significant aspect of Italian industrialisation, and worthy of international consideration.

The introduction will emphasise the historical importance of the 'city of factories', Sesto San Giovanni. Its main focus will be on the most significant aspects, with the aim of providing exhaustive answers to the questions set out above. In order to avoid unnecessarily repetitive descriptions, the appendix contains a general summary of cases and types of welfare provided by companies.

\section{Paternalism versus mutual interest}

Early approaches to the phenomenon of paternalism considered paternalism a form of domination by companies beyond the production line. However, these approaches proved incapable of fully accounting for the development and duration of 'the company town's and, more generally, the development of large companies at the turn of the nineteenth and early twentieth centuries. It is therefore useful to define paternalism: 'paternalism as a political, societal or entrepreneurial ideology characterised by the hierarchical pattern of an institution or enterprise based on patriarchy' ${ }^{10}$ Several forms of paternalism have been identified, some of them 'heavier', where the degree of subordination of between 'patriarch' and workers may take on a 'proto-totalitarian attitude', while others are 'softer', characterised on the other hand by greater 'inclusion in the system of social and cultural relations.'1

In Italian historiography - at least in more dated reconstructions - 'totalitarian' interpretations of paternalism were long dominant, emphasising the hierarchical relationship of subordination between 'master' and workers, while commonly shared aspects concerning mutual interest were long relegated to the margins. Thus 'paternalism', used mainly in its 'heavy' variant, acquired a negative meaning. ${ }^{12}$ Only recently have a number of scholars shown how philanthropic, mutually beneficial currents also run through paternalism ${ }^{13}$ as opposed to mere subordination. Precisely because of this distinct emphasis, our intention is to focus attention on aspects relating to 'mutual interests', which, being present in and not merely in contrast with paternalism, have been largely neglected, without adequate recognition of their role. In short, while 'paternalism' and 'mutual interest' are not considered to be in opposition to each other, it is emphasised how much more significant social measures 
fostering mutual co-operation are, compared with mere subordination, without failing to recognise that in welfare patriarchal forms between employers and employees lasted over time, with recourse to typical images and symbols of the company as 'one big family'.

In addition, the 'negotiated loyalty' ${ }^{14}$ of American welfare capitalism was secondary in Italy, especially during the crucial years between the two World Wars as a result of restrictions imposed by the Fascist regime on trade-union relations, thus preventing the parties from freely negotiating, including with regard to social services provided by companies. We can find 'negotiated loyalty', partially, in the companies' sport and recreation activities.

Mutual aid generated conspicuous 'economic advantages for both employer and employee. ${ }^{15}$ The search for 'a sense of identification between employer and employee' became one of the main objectives of company welfare, capable of restoring the personal relationship that had existed in smaller firms ... above all the welfare worker was intended to embody middle-class virtue', which would justify 'welfare programs strictly in terms of economic rationality. ${ }^{16}$

The premise above enables us to better understand the origin, evolution and role of company towns in the process of industrialisation in Italy. In particular, it allows us to review the paternalistic perspective that has long dominated in Italian historiography, especially in studies relating to company towns. ${ }^{17}$ In particular, the paternalistic approach is unable to account for cases of company towns from the beginning of the twentieth century onwards, especially in capital-intensive sectors such iron and steel, mechanical engineering and the chemical industry. ${ }^{18}$ This phase enriched the social activity of companies, which went beyond mere house-building to extend to the concept of the welfare company.

In this perspective, the case of Sesto San Giovanni suggests that the main driving forces behind the company towns were commonly shared values, such as belonging to a cohesive community $^{19}$, and the mutual interest on behalf of both the entrepreneurs and workers alike in building efficient companies that would last over time. ${ }^{20}$ This was achieved by building a highly developed welfare system which spread from the factory to include workers' families in the network of social services too.

For this reason, the case study of Sesto San Giovanni offers many clues in support of a more convincing understanding of the 'community company', such as the idea of a process of 'building' shared between the entrepreneurs and the workers, as opposed to paternalism imposed on the latter by the former. Sesto San Giovanni provides an opportunity to examine the issue more closely, as from its development at the beginning of the twentieth century through to its decline after the Second World War, the involvement of companies in governing the life of this community progressively waned.

\section{Company towns in historical perspective}

The variety of company towns is such that it is difficult to describe them in a single, unequivocal manner. Their significant and numerous variations do not permit the adoption of rigid boundaries to identify successive historical experiences. John G. Garner identified the company town as 'a settlement founded or sustained by a single enterprise that is also its chief employer', tracing the origin of the definition back to the period between the nineteenth and twentieth centuries. ${ }^{21}$ The satisfaction of basic needs pushed companies 'to build houses, stores, and schools (that) did not exist at the outset', thus increasing their influence on the life of the communities created around the areas of production. ${ }^{22}$ For a 
long time, researchers concentrated their attention on architectural and urban aspects, while recently dedicating growing attention to 'the changing structure of industrial technology and social relations that composed the production process at (their) core ${ }^{23}$, thus creating a strong drive towards an interpretation 'of the company town as a part of the movement to restructure industrial enterprise and work relations from the chaotic disorder of the nineteenth century. Rationality and the social gospel were shared texts rather than antagonistic doctrines. ${ }^{24}$ However, this revision has not met with adequate attention on the part of business historians. ${ }^{25}$

The expansion of company-town boundaries took into consideration not only the communities created around a single business but also those connected with groups of companies, where the discriminating variable was 'the substantial part of the real estate and houses.' ${ }^{26}$

Before presenting the case study of Sesto San Giovanni, it will be useful to provide a brief overview of company towns in Italy in the early 1930s (Table 1). It will also be helpful here to outline the salient aspects of Italian company towns in the period in which they reached maturity - that is, in the 1930s, when some research was conducted at national level. This research was promoted at the national level by the Association of Industrialists. The study allows us to describe the main aspects and characteristics of Italian company towns, although the research itself lacks any systematic or exhaustive data-gathering criteria, being characterised instead by descriptions of the many projects realised in company towns in a clearly celebratory tone.

The fact that company towns alone employed around 240,000 workers shows how important this organisational form was and leads to further classifications. ${ }^{27}$ One of these regards the size of companies around which company towns were created. Their distribution according to the number of workers highlights a wide range of situations where, besides 'big names' such as Fiat, Montecatini, Terni and Snia, there was an equally significant presence of smaller companies. In the former case, these were complex organisations with production plants distributed throughout the area and characterised by specific solutions (such as the mining villages of Montecatini) ${ }^{28}$ or by a very high degree of concentration (such as Turin, the 'city industry' of Fiat) ${ }^{29}$ In the smaller categories, especially in the minor ones, there were cases where a deeply rooted local presence constituted one of the main factors for a company's life-span, as is well documented by cases such as Beretta in Gardone Val Trompia (Brescia), whose origins date back to the sixteenth century. ${ }^{30}$ Regional location is also highly revealing. ${ }^{31}$ Although regions with a solid industrial base such as Lombardy and Piedmont dominate, border regions such as Veneto and Liguria also stand out in terms of numbers of companies and workers. A few cases are found in central Italy, while Southern Italy is completely absent. Finally, distribution by production sector completes the picture. The textile sector is the most widespread, confirming its importance to the industrial

Table 1. Company towns and workers in Italy, 1933.

\begin{tabular}{lcc}
\hline Workers per unit & Number of company towns & Total workers \\
\hline More than 10,000 & 5 & 127,500 \\
Between 5000 and 10,000 & 7 & 50,363 \\
Between 2500 and 5000 & 7 & 28,611 \\
Between 1000 and 2500 & 11 & 19,462 \\
From 500 to 1000 & 12 & 8755 \\
Up to 500 & 11 & 4205 \\
\hline
\end{tabular}

Source: L'Italia nelle sue opere assistenziali (Rome, 1933). 
system as a whole, as well as the specific management structure adopted. Indeed, in terms of internal structure, cotton (with 11 factories which employed 24,940 workers) and wool (eight factories and 21,000 workers) cover the earliest experiences and those that lasted longest - for example, the workers' villages of Crespi d'Adda ${ }^{32}$ and of Campione del Garda (cotton) $)^{33}$ or Valdagno and Schio (wool). ${ }^{34}$

Company towns thus prove to have been an effective solution that could adapt to a variety of different situations as far as social and cultural conditions were concerned, besides the employment of a wide range of technologies and managing structures. The cases cited above confirm how company towns represented an adequate management solution for the needs of companies and workers because they were capable of 'building real communities with services that were sometimes relatively sophisticated [,] quite refined' and suitable 'to the context and type of relationship that was established with the surrounding settlements. ${ }^{35}$ These solutions usually included houses for workers and employees, or canteens and boarding houses to reduce commuting, especially for women. The same attention was dedicated to hygiene conditions and medical assistance provided to the workers, with hospitals in the most organised towns, or with contributions towards medical expenses in smaller-scale contexts. It should be highlighted how schooling and training were essential for companies, especially those committed to rationalising production and management, who provided the same level of education as the standard school system, or sometimes even higher. Therefore, they were not only instrumental to the company's need to function but were also favourably welcomed by the workers and their families. Training also extended to other activities, such as cultural entertainment and sports, which were based on voluntary participation, another sign of genuine participation in the factory community.

This social aspect of companies led to the central issue of class conflict being abandoned ${ }^{36}$ in favour of a broader understanding of the social bonds constituting enterprise communities. ${ }^{37}$ Thus the entire area of settlement of factories has become a subject of study, along with related infrastructure such as housing, health and recreational facilities. ${ }^{38}$ The focus on social services in favour of workers has spread beyond the employment contract to include family life, health and child care ${ }^{39}$, dedicating specific research to specific forms of assistance, such as seaside and mountain-based summer camps ${ }^{40}$ promoted by companies, or further considerations concerning contexts which have been extensively studied such as the 'steel cities' of Terni or Dalmine. ${ }^{41}$

In this respect, in terms of size and importance as an industrial extension of Italy's main economic area, Milan and the Lombardy region, Sesto San Giovanni represents a context of primary importance for an understanding of the issues outlined above.

\section{Sesto San Giovanni: the exemplary city of factories}

Although unique in some ways, Sesto San Giovanni is nevertheless fairly representative of a number of comparable towns in Italy sharing similar characteristics during the same period. ${ }^{42}$ This case study enables a better understanding of the industrialisation process, consequently highlighting the necessity to understand which elements made them particularly suitable to reconcile various production aspects, and, ultimately, to understand why they died out. ${ }^{43}$ Its transformation from a small rural village to a large industrial hub was brought about by the combined intervention of entrepreneurs, who built the most important 
factories in the area, and the main landowners of the rural village, an involvement mediated and made effective by the most important national and international financial institutions. ${ }^{44}$

The farming village of Sesto San Giovanni was chosen for its ideal location. Situated in the vicinity of Milan, it underwent a radical transformation, from an agricultural area to the epicentre of Milan's industrialisation. This transformation was spurred by the fact that Sesto San Giovanni lay alongside a number of major transportation routes, with the railway line connecting it to Central Europe and easy access to Lombardy's population centres. ${ }^{45}$ The growth of the textile industry in the second half of the nineteenth century encouraged firms operating in technology-intensive industries, such as steelmaking, mechanical (vehicle) and electromechanical engineering, to set up here.

The period of the 'city of factories' began in the early years of the twentieth century. It would last in its unique form through to the years immediately following the Second World War. ${ }^{46}$

The planning of the new urban settlement saw the involvement of the company founders Ernesto Breda and Giorgio Enrico Falck, the main architects, together with Ercole Marelli, of the 'visible hand' that governed the 'city of factories' in the years of its foundation. ${ }^{47}$ Their location outside of Milan allowed these companies to have a deep influence on the way the emerging industrial society was being built. This was the result of an overall restructuring of the regional economy, which benefited from a wave of technological innovations such as electricity, and occupied in a collective effort to reorganise the manufacturing activities traditionally rooted on the territory, such as textiles, metallurgy, mechanical and chemical engineering, including the modernisation of agriculture. ${ }^{48}$ Sesto San Giovanni played an important role as a breeding ground as far as economic, social and cultural changes were concerned, thanks to three main factories which left their mark on its development: Acciaierie e Ferriere Falck (Falck - iron and steel); Ernesto Breda (mechanical engineering); and Ercole Marelli (electromechanical engineering). The three companies, joined by Magneti Marelli in 1919, acquired a sizeable part of the municipal land and rapidly extended their production plants to areas specifically dedicated to industrial sites. ${ }^{49}$

In the space of a few years, Falck became leader of the 'Po Valley' steelmaking industry and established itself in the electrical steel industry, investing in hydroelectrical power plants in the Alpine valleys and in the construction of large electric steel plants in Sesto San Giovanni. The steel produced was then worked in the factories of Sesto San Giovanni and others located elsewhere in Italy. ${ }^{50}$

Breda was founded in 1866. However, it was only when it moved from Milan to Sesto San Giovanni that it was able to establish its national leadership in railway engineering. The First World War led to its diversification with the opening of a steelworks and the manufacture of war materiel. Subsequently Brada expanded its mechanical and electromechanical engineering output, and in addition to Sesto San Giovanni where its main 'sections' operated, expanded its operations across the whole of Italy. ${ }^{51}$ Its rapid diversification was one of the factors which rendered it rather fragile financially and the death of its founder, Ernesto Breda, in 1918, followed by varying family fortunes, led to it being acquired by the State through IRI, and then sold in 1935 to the De Angeli Frua family, industrialists in the textile sector, who were forced to sell it after the Second World War due to manufacturing conditions leading to bankruptcy. ${ }^{52}$

Finally, Ercole Marelli, which was founded thanks to the enterprise of its founder who gave his name to the company, first established itself as a manufacturer of domestic 
Table 2. Sesto San Giovanni: population 1900-61.

\begin{tabular}{lccc}
\hline Year & Population & Natural growth $^{*}$ & Migration movements $^{*}$ \\
\hline 1901 & 6986 & - & - \\
1911 & 13,477 & 1464 & 6398 \\
1921 & 19,205 & 1122 & 3621 \\
1931 & 30,974 & 2519 & 12,054 \\
1941 & 40,184 & 3268 & 6287 \\
1951 & 44,689 & 2013 & 2150 \\
1961 & 66,270 & 3173 & 23,159 \\
\hline
\end{tabular}

Sources: Varini, L'opera condivisa and Municipal Population Register. ${ }^{*}$ Difference compared with previous decade.

appliances (fans and electrical lighting systems), subsequently expanding its product range into components for electricity power stations. During the war years it produced electrical components for vehicles and in 1919, in collaboration with Fiat, founded Magneti Marelli, which became the leading Italian manufacturer of electrical parts for motor vehicles and opened up to partnerships with major European companies such as Bosch. In Sesto San Giovanni the Marelli group expanded to count no fewer than four factories and, thanks to its forward-looking managerial organisation, pioneered the adoption in Italy of organisational and management models based on Taylorism. ${ }^{53}$

The most conspicuous effect of the establishment of the three plants, starting in 1903, was to attract large numbers of migrants. During the short period between 1905-6 and the First World War, the population of Sesto San Giovanni increased from a few thousand to over 15,000, an increase of about 7500 people (Table 2). ${ }^{54}$

The arrival of manpower imposed rapid expansion in housing for commuting workers, at first provisionally, and later on a more permanent basis for workers who chose to move closer to their workplaces. Growing demand for public services created heated disagreements between companies and public authorities. ${ }^{55}$ Disputes arose over amounts to invest in city development, which would long fail to keep pace with the needs of the local population. Indeed, public institutions were constantly urged to increase investment in public works, with generally unsatisfactory results. ${ }^{56}$ Consequently, the only organisations that could respond adequately were the companies: driven by remorselessly expanding production, which was boosted still further by the wartime mobilisation that started with the First World War, they found themselves in the position of having to take direct measures themselves to satisfy the needs of a rapidly growing population. ${ }^{57}$

When the war was over, large companies set out to consolidate their manufacturing growth and thus needed to attract labour ${ }^{58}$ in addition to improving workers' professional skills. Both aims required settled workers and a reduction in staff turnover (Table 3 ). This goal could be achieved by building adequate accommodation facilities, from dormitories to houses in the short term, while to retain them on a more permanent basis it was necessary to settle their families and organise their professional training. This all required extensive action at the social level in order to make workers 'faithful' to companies, thereby involving them to an adequate degree in developing production. This dual aim of satisfying the needs of workers and the production needs of companies constituted the basis of mutual interest among the parties involved. 
Table 3. Sesto San Giovanni: Falck, Breda, Magneti Marelli and Ercole Marelli employees (1904-61).

\begin{tabular}{ccccc}
\hline Year & Falck & Breda & Magneti Marelli & Ercole Marelli \\
\hline 1904 & & 373 & & $500(1906)$ \\
1911 & $800(1913)$ & 1675 & & 1500 \\
1923 & $5350^{* *}$ & $4150(1925)$ & 880 & \\
1934 & 3770 & 4749 & $4612^{* *}$ & 2584 \\
1944 & 8811 & $11,172(1944)$ & 6901 & $5213(1940)$ \\
1950 & 8905 & 13,953 & 2313 & 5270 \\
1961 & 9449 & 5875 & $3001(1968)$ & 6086 \\
\hline
\end{tabular}

Source: Varini, L'opera condivisa.

**Includes employees on all company sites.

\section{Welfare capitalism: housing, health, education and training, leisure}

It was precisely this 'implicit and silent loyalty'59, to companies which became the preliminary condition for them to be able to conduct their productive activities. Company management was well aware of this, explicitly pointing out that providing for workers' welfare had direct production aims ${ }^{60}$, while references to 'paternalism' were criticised or relegated mainly to moments of celebration or public holidays, such as the granting of scholarships or the distribution of Christmas gifts.

Stages in company welfare mark company-development timescales, beginning with worker accommodation (houses and dormitories) and extending to workers' health, with healthcare followed by services expanding beyond the factory walls, from workers to their families, with workers' villages, nursery and primary schools through to recreational associations. This schematic sequence focuses on workers' accommodation, before examining health and social care with schooling and vocational training and finally concluding with a brief look at leisure time with recreational associations.

\section{From dormitories to workers' villages}

The first buildings of this impressive project were built with the financial participation of the larger companies in the friendly societies which were created at the turn of the twentieth century and which were providing workers with support and assistance, despite not having the economic resources to meet growing demand, especially for housing. ${ }^{61}$ As a result, the building project was funded directly by companies and started in the years immediately after the factories were built, continuing relentlessly in the following decades, although according to different approaches at different stages. ${ }^{62}$ At first, the urgent need for housing limited companies to simply providing lodgings for workers in dormitories and boarding houses that offered minimum services as far as accommodation and dining facilities were concerned. Such solutions led, for example, to the recycling of some old farmhouses ${ }^{63}$ that were bought and refurbished by the main companies located in Sesto to accommodate workers. ${ }^{64}$ As time passed, however, the need to stabilise manpower spurred companies to embark upon more complex, longer-term town-planning projects. Among these companies, Falck took a leading role in experimenting with suitable town projects and became a reference point for other companies.

Immediately following the First World War, Falck started to plan the first workers' village, which was provided with all the necessary services to satisfy the needs of a fledgling community connected by the same working experience. Due to the complexity of the project 
and the size of the investment required, building work continued throughout the 1920s and was only completed at the beginning of the 1930s. Once completed, the first Falck village, a forerunner of similar future projects, boasted more than 1000 inhabitable rooms and all the services required for the life of a whole community. ${ }^{65}$ Workers' houses were built in small groups and inhabited by a small number of families ${ }^{66}$ in order to preserve their compactness and avoid episodes of family disintegration. Especially for Falck, the objective of preserving family unity became a central concern of the entrepreneurial activity carried out by the founder, Giorgio Enrico Falck, and continued by his successors, inspired by their religious faith. ${ }^{67}$ Preserving family unity also had important economic implications as it helped ensure that workers - in particular specialised workers - settled permanently. The need to counter an excessively rapid turnover of workers, especially after adequate training, led companies to offer good housing conditions. ${ }^{68}$ These conditions were also appreciated by workers themselves, who found that Falck villages represented an ideal environment to build significant bonds with other families in the community. ${ }^{69}$

In the recollections of the elderly, life in workers' villages - with no particular distinction between Breda and Marelli, but to a particular degree in the case of Falck - was based on a number of key pillars. Work represented the bond on which identity was founded, belonging to a community, characterised by values such as relations of solidarity between residents. This solidarity was the result of shared life experiences, beginning with the nursery schools promoted for example by Falck, which continued at primary and vocational schools and, for the most deserving, scholarships for university studies. ${ }^{70}$

As to why Falck acted directly in these spheres, the reasons that were repeatedly stated - at least initially - were 'to endear the location to the workers', without any specific aim of 'controlling' workers. Indeed, the company management initially tried to involve the local municipality. ${ }^{71}$ Only when this failed was Falck forced to act directly and to cover the additional costs of building streets, sewers, aqueducts and everything else required for the new settlements to function. ${ }^{72}$ Finally, concerning control of the Falck village, it should be pointed out that the 'discipline' applied by the company was much more a way of making some hygiene practices widespread and fostering orderly cohabitation than it was a way of imposing company domination over the communities linked to it.

The substantial investments made by the main companies had a collateral effect on the housing market ${ }^{73}$, which had previously been characterised by strong increase in demand and limited supply. Rents fell and speculation, which would have been detrimental to workers' interests, was avoided. ${ }^{74}$ Even though there was a risk of company housing being used as an instrument to control labour, there were never enough cases, at least in the early decades, to be able to talk of blackmailing workers to whom the houses were assigned by the companies. ${ }^{75}$ Then again, the chronic housing shortage created constant public-order issues that neither the housing market nor the borough authorities could cope with. ${ }^{76}$ These same companies significantly changed the way they intervened in the building sector during the 1930s. From being directly involved in house-building, Breda and Falck later preferred to work with public bodies such as the housing office in Milan ${ }^{77}$, so as to reduce further the risks of an arbitrary use of accommodation. ${ }^{78}$

Co-operation with the Fascist Istituto Autonomo Case Popolari of the province of Milan saw these large companies, above all Falck and Breda, participate with the sale of land and specific financing for the building of houses for their workers. The companies restricted themselves to overseeing building times and uses of housing, without taking on direct 
management of them. Housing for around 500 families was built by Falck alone ${ }^{79}$ while over 1900 people lived on land donated by the company. ${ }^{80}$ They were thus interventions where mutual interest prevailed: companies ensured the availability of labour, while workers benefited from housing near the workplace and in favourable health and economic conditions. ${ }^{81}$

Rules and regulations for tenants were mainly geared towards fostering peaceful social coexistence and avoiding foreseeable conflicts deriving from the absence of common traditions and established customs, as opposed to giving the company any discriminatory power. ${ }^{82}$ Moreover, the need to establish rules of behaviour was born out of the necessity to integrate families from increasingly far away, a trend which through the years extended to the whole of Italy.

Breda operated in a similar fashion. It started planning houses for its workers in 1906 and in 1910 completed work on 26 estates, including related services such as laundries, electricity, nurseries and gardens. ${ }^{83}$ Breda specifically indicated in the company literature that this was to create an 'emotional bond' with their workforce. For this purpose, the companies started building houses to rent out at below-market prices to their workers, with undeniably substantial advantages for the company, which enjoyed a higher degree of collaboration and reduced potential conflicts. ${ }^{84}$

All in all, these policies enabled companies to control the price of housing, not just for their workforces, but for the population as a whole. Furthermore, the need to house workers meant that a great deal of care and attention was put into urban décor ${ }^{85}$, and town planning consisted mainly of detached houses based on the Garden City model. ${ }^{86}$ This choice distinguished housing provided by the companies, which took a very different approach compared to other available private accommodation, characterised by a high degree of decay and overcrowding, as reported by surveys carried out at the beginning of the 1920s by public authorities. ${ }^{87}$ Until at least the 1950s, companies made up for the lack of substantial public investment, especially on the part of town councils, whose house-building activities were limited. ${ }^{88}$ For confirmation of the vital importance of companies in this respect it is sufficient to note that during the tough years of reconstruction after the Second World War, between 1948 and 1950, Falck and Breda built a total of 850 rooms and 71 new flats, while public investment was almost non-existent. ${ }^{89}$

\section{Health care and schooling}

Companies did not act on behalf of their workers in the area of housing alone. In order to create cohesive communities, other aspects of workers' lives needed to be considered. Specifically, companies satisfied a whole range of needs that workers and their families had. Above all, special attention was given to social welfare in order to protect workers in terms of social security and health care..$^{90}$ This type of assistance was often limited to workers. However, in many cases it was progressively extended to cover their families and residents of Sesto San Giovanni, including those not directly employed by the companies.

The first area in which the companies intervened concerned hygiene conditions and workers' health, with the establishment of sickness funds and health care, including specialised surgeries such as those provided by Breda, Falck and Magneti Marelli. Health care also extended to mothers and children with the creation of summer and winter camps, nursery schools and the supplying of food for children. These measures intensified, especially during the 1920s, and in the following decade extended to the whole town population. For 
example, the social services offered by Magneti Marelli for mothers-to-be and newborn babies opened in 1933, offering such high quality that the female workers were considered 'the most privileged working mothers in Italy.91 This view was echoed by the female workers benefiting from the services: the 'factory that fed us, Magneti Marelli was a wonderful factory', as evidenced by records concerning assistance for women who found a centre dedicated to looking after their own children in the company nursery. ${ }^{92}$

As part of the health service, special attention was also dedicated to safety at work (despite meeting with continuous opposition on the part of workers, companies made substantial efforts towards this goal). ${ }^{93}$ Falck, in particular, created a permanent health and safety service operated by specialised medical staff, which also extended to external workers. ${ }^{94}$

Another important area of intervention was that of schooling and professional training. Community aims such as ensuring basic education for all young people came together in this sector, which included elementary and professional schools, and these aims were shared by the companies that required skilled manpower. Initiatives to promote education were diverse and included, at their height, two elementary schools (at Falck and Breda), three vocational schools, and a wide variety of grants (from scholarships to book vouchers) aimed at increasing education levels among the population of Sesto San Giovanni. ${ }^{95}$

Some figures will make the companies' commitment to education and vocational training clear. During the decade from 1922 to 1931 Breda, through the Ernesto Breda Foundation, funded 2357 scholarships for primary-school pupils, 277 for middle and high schools and 509 for vocational schools, making a total of 3143 beneficiaries ${ }^{96}$ among the,approximately 4500 workers concentrated in Sesto San Giovanni during the period. ${ }^{97}$ Breda also set up its own vocational school with a three-year programme. In the 1947/48 academic year, it was attended by 165 of its factory apprentices. ${ }^{98}$ In the same area, Ercole and Magneti Marelli established specific Officine scuole (factory-schools). ${ }^{99}$ Further proof of mutual interest $v i s-\grave{a}-$ vis Sesto San Giovanni society, it should be mentioned that the companies lent their support to the vocational school specialising in mechanical engineering and design promoted by the local Società di mutuo soccorso or mutual benefit society, which in the 1930s received over a third of its funding from the aforementioned companies, compared with less than one fifth from students. ${ }^{100}$ Similarly, during the post-war period the sphere of vocational training was dominated by companies, so much so that in 1956 there were eight vocational institutes, no fewer than five of which were 'private' where the names of Breda and Marelli feature, in addition to internally held courses for their own employees. ${ }^{101}$

In particular, it is important to emphasise that vocational schools established to provide the workforce with the knowledge and skills required to operate production plants were also appreciated for the career opportunities they opened up. Indeed, looking at workers' comments, it is clear that they viewed vocational training as an important opportunity to 'specialize and become a good worker', and to have the chance to apply for coveted positions such as supervisor or head of department. ${ }^{102}$ Learning a trade became a distinctive feature that expressed a specific work ethic widely shared among the workforce of Sesto San Giovanni, an approach strongly supported by the companies. ${ }^{103}$ Proof of such involvement can be found in enrolment numbers at the school funded by Marelli, established in 1929, which rose from 152 in 1933 to about 1550 in $1939 .{ }^{104}$ A similar increment was recorded in the school set up by Falck, which in 1941 had over 800 pupils on its books. ${ }^{105}$ The companies were also active in public education, such as support for about 4000 young students in the second half of the 1930s thanks to the companies' substantial funding. ${ }^{106}$ 


\section{Leisure time: company recreational associations}

Services offered by the companies included leisure activities such as libraries and sports - in particular winter and motor sports - painting courses, drama, literary competitions and so on, which were organised by workers' clubs in the 1930s. ${ }^{107}$ The significant role of company recreational associations and workers' clubs is reflected in the total number of members, which reached 38,756 in 1943. Workers' clubs organised by the companies considered in this analysis played a central role in terms of size and activities. Starting in the 1920s, they played a dominant role, especially in promoting and supporting sports. For example, at Ercole Marelli there were groups dedicated to climbing, swimming, canoeing, motorcycling, athletics, basketball and many others. In addition to sport, there were amateur drama and musical groups which met in company buildings that included a theatre, a library and dedicated reading rooms. ${ }^{108}$ Falck set up a building dedicated to the workers' club including a cinema, a gym, a bowls green, a library and also a sports field, near to one of the two company villages. Thirty sections gave life to leisure time at Falck, primarily in the organisation of various sport disciplines. And finally, Breda, which boasted the largest workers' club in Sesto San Giovanni, was distinguished by its three canteens and food and clothes shops offering staff discounts.

Workers' clubs played a crucial role in sustaining the town population during the Second World War. ${ }^{109}$ It is important to note how marginal Fascism was to this environment. Although individual companies formally respected the propaganda directives issued by the government, they also strongly defended their independence and autonomy. ${ }^{110}$ The distinctive element of all these initiatives is to be found in the common purpose shared by all the social forces at play, primarily by the companies themselves, more than in an authoritarian approach aimed at dominating a community enclosed within the company's boundaries, as demonstrated by extensive and passionate participation on the part of the workers and backed up by various facts. For example, Ercole Marelli was portrayed by the socialist press as an 'affable, courteous man without affectation, who takes care of workers as if they were brothers. ${ }^{111}$ References to family bonds were a recurring theme in the letters written by the workers, in which mentions of 'our big Marelli family' are found frequently, underscoring how intensely workers felt themselves to be a part of the company. ${ }^{112}$ Even the most critical judgements, expressed by union representatives during the post-war years, recognised how important 'the actions ... towards the workers (involving individual bonuses, loans, retirement funds, housing, etc.)' had been. Although they were described as 'paternalistic,' they were viewed in quite a favourable light overall. ${ }^{113}$

\section{Reciprocal interests: mutual bonds}

Although voices opposed to company management were heard, the 20-year-long Fascist period and consequent negation of union freedom meant that these did not significantly interfere with the alliance between the companies and the workforce. ${ }^{114}$ It is more pertinent to highlight the mutual bond, a bond that became decisive in the years to come when, after the headlong rush of development in the early years, the companies had to rationalise their organisation. In this respect, the example offered by Magneti Marelli is suitably representative of the main industrial groups of Sesto San Giovanni. Magneti Marelli was a pioneer 
in the adoption of a scientific management approach inspired by Taylorism and the standardisation of the production process, widely described in the company in-house magazine Sprazzi e bagliori. The magazine was distributed among workers and amply described the company's intentions. In particular, the workers' club activities, which the company proudly pointed out as prefiguring similar provisions by the Fascist regime, reaffirmed the intent of reinforcing the sense of belonging to 'our work family', a family to which 'our father Marelli and our managers' had paid a lot of attention right from the start, in order to bond the 'most loyal (and skilled) workers' with it. ${ }^{115}$ That this was not just rhetoric and that there was a willing participation of the workers is confirmed by the widespread and constant participation in the initiatives promoted by the company, as is meticulously reported by their in-house magazines. ${ }^{116}$ It cannot be convincingly argued that these activities reflected a mere state of subordination on the part of the workers, especially in a context such as Sesto San Giovanni where they could freely move from one company to another. It is significant that Magneti Marelli and other companies in Sesto San Giovanni 'acted directly to retain their workforce' and the initiatives they promoted, including those relating to safety at work, aimed to improve working conditions and reinforce 'loyalty and consensus among workers. ${ }^{117}$ This was a central aspect for the smooth operation of the complex managing structure at Magneti Marelli. The main preoccupation for the company management was to maintain a continuous production flow. This ultimately depended not only on the careful planning of the different work stages but also on the twenty years 'of experience (of the workers) ... that adhered to the actual practical needs of the workshop. ${ }^{118}$ After all, the collaboration of all the people involved with production, who shared the benefits produced, was based on reciprocal interest.

Breda offers a further example that confirms the decisive role played by the workers in ensuring the functioning of the company. At the end of the 1920s, the company embarked on a 'scientific' rationalisation of management, which ultimately did not bring the positive outcome expected. The people who had planned it, mainly external consultants, had to recognise that the best production results were achieved thanks to the professional approach of the workforce and the high degree of autonomy with which workers operated within the factories. ${ }^{119}$ Similarly at Falck, the importance of the workers' professional and organisational skills determined the factory hierarchies that were fundamental to the smooth operation of the smelting furnaces and to forge steel products. ${ }^{120}$

Professional skills were held in such high regard that workers spontaneously engaged in the production of 'masterpieces' to prove the level of skill that they had reached, hence confirming their role within the factory. ${ }^{121}$ In general, the importance of reciprocal duties as a company value is referred to constantly and persistently during the post-war period. In fact, one year after the death of Falck's founder, the board of directors noted that 'responsibility towards one's workers' is based 'on the most loyal and active collaboration. ${ }^{122}$ The welfare system was appreciated by the recipients themselves and acknowledged as belonging to that principle of 'social wellness' that guided the founder, Giorgio Enrico Falck, in his business activities. In the account given by a family of workers, who had lived in the Falck village for some generations, company welfare was perceived as a means of 'bonding the workforce to the factory as if it was their safest harbour: if work is dedication, it means above all that one has grown roots' and it was not just 'the result of a utilitarian calculation.' ${ }^{123}$ 


\section{The slow decline}

The company towns of Sesto San Giovanni reached their highest peak during the war years and then slowly declined in the post-war years. Many factors played a part in this breakdown in the functions of the company town, including welfare, starting with the reconstruction that began after the end of the war. In the post-war years, these companies engaged in costly plant-modernisation programmes that required large investments and were carried out also thanks to the substantial help granted by the Marshall Plan (officially known as the European Recovery Plan). ${ }^{124}$ Especially at Breda, reconstruction meant major reductions in personnel and in general this effort limited the possibility for companies to maintain a high level of social intervention. The process of reconstruction took place against the background of an intensely conflictual climate, which was one of the factors which contributed to dissolving existing social cohesion, a union-based conflict linked mainly to national politics and to the deep economic crisis that affected the entire Italian economy. ${ }^{125} \mathrm{~A}$ comparison between Breda and Falck is instructive here. The former became the centre of a long and bitter conflict with workers, suffering decreased demand for guns and train equipment the most, while the latter found that the recovery in iron and steel demand limited the duration of the conflict with the unions. ${ }^{126}$ In the face of such a challenge, the establishment of collective bargaining as a form of regulating the relationship between workers and management played a part in loosening the communal bond.

Other factors played a part in dissolving the distinctiveness of the 'city of factories'. The most important was the role of government, from the municipal to the national level, as its presence restricted the large companies' scope of action. ${ }^{127}$ The rise of a national welfare system and the impact of increased taxation also added to the costs borne by the companies. This in turn reduced resources available to provide company welfare. Indeed, company documents persistently stated that the reason for declining company welfare was ever-growing state interference. ${ }^{128}$ Falck in particular, which had become the main company in Sesto San Giovanni after cuts at Breda and Ercole and Magneti Marelli ${ }^{129}$, reported that the cost of labour alone had increased by $52 \%$ in the four years from 1959 to 1962, an increase due to both union negotiations and higher taxation imposed by the State. ${ }^{130}$ Ultimately, the gradual closing down of the companies themselves brought their role to an end, first through the considerable downsizing of Breda, which became a state-owned company, followed by the closure of Ercole and Magneti Marelli, and then Falck. ${ }^{131}$

A clear indication of the end of the company town of Sesto San Giovanni is found in population statistics. While the population of Sesto San Giovanni as a whole grew from 44,935 in 1951 to 91,080 in 1971, the number of workers employed by the big companies declined in the same period from about 24,000 to less than 15,000. ${ }^{132}$ However, it should be pointed out that what the companies promoted did not completely disappear. On the contrary, in an important sector such as training, for example, the company schools established by Falck, the Marelli group and Breda joined after the Second World War to become one technical school managed by the Salesian Fathers. ${ }^{133}$

\section{A brief general conclusion}

The boom years of the 1950s coincided with the end of expansion for the large companies in Sesto San Giovanni. They had already reached their peak and were about to start a slow 
decline that was to be completed in the following decades - although as already mentioned earlier, this did not coincide with the decline of Sesto San Giovanni itself. The network of services they had created became a key factor for the development that followed. Other institutions such as the town council and small- and medium-sized industries managed to fill the gap left by the large companies. Specifically, the municipality took over the management of welfare from the companies. ${ }^{134}$

The rich experience of Sesto San Giovanni also shows that differences in the form of management - Falck was a family business, Ercole and Magneti Marelli had their own management structures, and Breda was state owned during the final years considered here - did not substantially affect the kinds of social interventions implemented by these companies. The key differences between the companies analysed here are to be found mainly in their way of managing their relationship with their workers, more than in the substance of such actions. Nevertheless, it should be pointed out that the companies under consideration left welfare management to specific functions within the company hierarchy, while the involvement of the owners - especially family members - had a mainly celebratory role. The survival of 'paternalistic' methods is observed mainly at Falck. As well as occupying key roles on the company's board, members of the Falck family were active in providing social services. Their presence became important on public occasions, such as the inauguration of nursery schools or the distribution of Christmas gifts and scholarships and awards for long service $^{135}$, and was key to reinforcing the sense of belonging to the 'community company'. Nevertheless it was Falck, long considered the most paternalistic of the Sesto San Giovanni companies, which established a 'care service' run by a 'team of ten caregivers' trained in a specific 'social service school' set up in Milan by the successor to the company's founder, Enrico Falck. The work of these caregivers was to be inspired by 'reciprocal trust which gives rise to active cooperation on the part of all staff' ${ }^{\prime 36}$, and emphasised the social nature of the company based on satisfying the needs of the entire community in which it operates. ${ }^{137}$ The concept of the company as a 'community' reflected the Falck family's Christian faith, in particular that of Enrico, the first-born son of the founder, Giorgio Enrico, who was called upon to succeed him. ${ }^{138}$ Forms of paternalism were extensively practised by Falck, and the day-to-day management of company welfare was entrusted to a specially created company board which was attuned to what was happening in other large companies. Ercole and Magneti Marelli in particular took more bureaucratic approach as such matters were provided for by specific company policies. ${ }^{139}$ At Magneti Marelli, the absence of a majority family stake (as the company had been constituted in collaboration with Fiat), company welfare was entrusted - in keeping with the vision of 'scientific management' that had characterised the company since the 1920 s - to the company management, which actually expressed views that were critical of paternalistic practices, but,which also acknowledged the attempt to 'endear' workers to the company to obtain productivity gains, while ensuring a 'reward for the intensity of the work required of them' in exchange. ${ }^{140}$ These arguments were reiterated by Antonio Stefano Benni, president of Magneti Marelli, who ascribed to 'opere sociali' or work in the community the goal of creating 'an atmosphere which makes the company one big family', contrasting with 'paternalism' the need to create the 'feeling of collaboration.' ${ }^{141}$ Similar ideas are found consistently in company literature, which repeatedly acknowledges the goal of increasing workers' productivity combined with that of seeking 'relationships characterised by greater cordiality and reciprocal understanding and respect 
between company and workers.' ${ }^{142}$ The notion of belonging to a 'big family' is even found in the commemoration of workers sent to fight in the Second World War. ${ }^{143}$

We may conclude that it was mutual interests more than restrictive paternalism that provided the common ground on which the success of 'the city of factories' was based ${ }^{144}$, which led the way to a 'compliance' ${ }^{145}$ and collaboration between all parties involved in production, who benefited in different ways. ${ }^{146}$ As the case of Sesto San Giovanni illustrates, behind the foundation of such large companies was the need to create communities based on long-term co-operation and agreement, as well as on the mutual nature of the contributions of both workers and entrepreneurs. This co-operation, as an esteemed Italian scholar has remarked, was capable of generating shared values that were 'incorporated into the company tradition' and led to the creation of 'collaborative and cohesive cultures' ${ }^{147}$, equivalent in many ways to other forms of 'father/child' paternalism found in other productive environments. ${ }^{148}$ This mutual sharing of duties and values would mark the whole life of the company towns of Sesto San Giovanni. ${ }^{149}$ The experience of the company town ended due to the reduction of economic resources available to the companies and also to the changed environment in which they operated in the post-war years. In addition, the rise of the welfare state and the formalisation of rules governing industrial relationships further contributed to the end of 'the city of factories.' ${ }^{150}$

\section{Notes}

1. Garner, The Company Town.

2. For a more recent discussion of company towns, see Borges and Torres, Company Towns.

3. For a recent historical overview of paternalism from an international perspective, see: Bonin, Thomes, Old Paternalism; "Patronage, Paternalism, and Company Welfare;" Gueslin, Le Paternalisme "rivisité." For a significant discussion on the nature of the paternalism: Price, "The Labour Process;" Joyce, "Labour, Capital," 67-76; Price, "Conflict and Co-operation;” Joyce, "Languages of Reciprocity," 225-31. The phenomenon of paternalism is further discussed in the studies of Tone, The Business of Benevolence; Mandel, The Corporation, and, arguing that corporate welfare has persisted over time, Jacoby, Modern Manners.

4. For a concise summary see: Benenati, "Cento anni;" Musso, Tra fabbrica e società, 43-8; Bigazzi, "Le permanenze."

5. Darley, Villages of Vision; on the company as a "historical subject," "governed primarily by affective logic and identity, based on faithful social relationships," see Sapelli, Perché esistono, 120.

6. Frey, Le ville industrielle; Schneider et al., Les Schneider.

7. Sheare, "Shelter," 19-27.

8. For a detailed overview of the various industrialisation processes in Italy and Europe, see Fontana, Le vie.

9. Crawford, Building the Workingman's, 6 .

10. "The system is seen as a family, with the patriarch as the central figure who defines business policy, including the rights of and the benefits for his workers, who depend on his goodwill, but without any legal claim," (Bonin, "Issues Concerning," 12).

11. Ibid., 14.

12. For an example - albeit an extreme one - see Guiotto, La fabbrica totale.

13. Trezzi, "Le opere sociali."

14. Zahavi, Managers and Welfare.

15. Crawford, Building the Workingman, 45.

16. Ibid.

17. “The Company Towns;" Ciuffetti, Casa e lavoro; Nesti, I villaggi operai, 11-13. 
18. Benenati, "Cento anni," 71-5.

19. Carera, ed., Opere sociali. With regard to the importance of community, see Walsh and High, "Rethinking the Concept," 255.

20. Bigazzi, "Le permanenze."

21. Garner, "Company Towns," 200.

22. Ibid., 201.

23. Melling, “The Company Town," 685.

24. Ibid.

25. Fridenson, "Business History," 19.

26. Davis, "Company Towns," 119.

27. In the same period, in Italy, 3,730,000 people were employed in manufacturing. See Carreras, "Un ritratto," 255.

28. Ciuffetti, "I villaggi."

29. Doty, “The Italian Detroit;” Berta, “Torino: una company," 9-22.

30. Morin, Beretta: the World's.

31. In order to evaluate the companies' geographical distribution, their registered or main office has been taken into account since the source used does not supply adequate information on the location of the individual production units. Regional distribution can be broken down, albeit approximately, as follows: Lombardy 37 companies, 138,963 workers; Piedmont seven companies and 60,430 workers; Veneto seven companies and 15,492 workers; Liguria five companies and 15,492 workers; Emilia Romagna two companies and 1,150 workers; Tuscany two companies and 1100 workers; Friuli Venezia Giulia one company and 3911 workers; Umbria one company and 13,000 workers.

32. Villaggi operai, 130.

33. Simoni, Oltre la strada.

34. Fontana, "Formazione ed evoluzione."

35. Fontana, "Dar casa agli operai," 21.

36. Merlo, Proletariato di fabbrica; Musso, Gli operai.

37. For a discussion on enterprise communities, see Amatori and Colli, eds., Comunità di imprese.

38. For a recent historiographical overview, see Ciuffetti and Parisi, Larcheologia industriale.

39. Minesso, Welfare e minori.

40. Ciuffetti, "Le colonie marine."

41. Raspadori, "Le opere sociali," Martinelli, "Le politiche sociali."

42. Ciuffetti, La città industriale.

43. With regard to the importance of the organisation of production in relation to the paternalistic approach, see Sapelli, Organizzazione del lavoro.

44. Varini, Lopera condivisa.

45. Sesto San Giovanni is situated in the immediate vicinity of Milan, with local and international rail links and easy access to labour from Lombardy's nearby Alpine areas, especially those with a major steelmaking tradition; Pavese, "I caratteri originali;" Varini, "The Steel Industry."

46. Trezzi, Sesto San Giovanni.

47. On the leading role of Falck, Marelli and Breda, see Amatori, "Entrepreneurial Typologies," 151-80.

48. Carera, I confini dello sviluppo; Colli, "Cent'anni."

49. Petrillo, La città delle fabbriche; Greco, Costruzione e trasformazione.

50. In addition to its main site in Sesto San Giovanni, consisting of four plants, Falck expanded to other mountain locations. The main ones included Vobarno, Dongo and Arcore in Lombardy and in the city of Bolzano; Frumento, Imprese lombarde; Bonelli, Acciaio per l'industrializzazione.

51. Breda concentrated its production of railway material, mechanical engineering, steel and aircraft in Sesto San Giovanni. It had other factories in Brescia and Rome, and a shipyard near Venice; La Breda.

52. Varini, "La genesi dell'impresa."

53. Cenciarini and Licini, Magneti Marelli. 
54. Sudati, Tutti i dialetti, 56-67.

55. Ibid., 152-3.

56. For an analysis of the lack of hygiene and the demand for housing during the 1910s, see Luigi Trezzi, "La società," 156, 164-8.

57. In a letter sent in 1923 to the municipal authority, the general manager of Falck complained that "our initiative involving setting up and promoting social security for our staff ... is virtually isolated." Cited in Sudati, Tutti i dialetti, 193.

58. Research conducted on Ercole and Magneti staff shows how, from the years following the First World War onwards, the adoption of Taylorism was accompanied by the stabilisation of labour in order to counter high levels of staff turnover; Licini, "Operai e operaie."

59. Unfortunately the workers' voices are sporadic. It has been very difficult to find evidence of the workers' judgement on the welfare company, above all due to the scarcity of sources.

60. Umberto Quintavalle, manager at Magneti Marelli, had the following to say on the subject: "The combination of welfare, humanitarian and recreational provisions that we have created and which are extended every day cost us extremely dear in terms of monetary sacrifices ... for the legitimate moral satisfaction of creating good for our employees ... as they are partly repaid by greater loyalty and productivity on the part of our workers." (Quintavalle, "Le possibilità pratiche," 24; Quintavalle, "Gli aspetti nazionali," 288).

61. Trezzi, "La convergenza verso," 125-6.

62. Ibid.

63. Alasia, La vita, 83-4.

64. At the beginning of twentieth century, Breda bought a farmhouse, Cascina Torretta, and Falck later bought Cascina Parpargliona and Cascina Rabina; Sudati, Tutti i dialetti, 183.

65. Fiorillo, "Il villaggio Falck."

66. The first Falck village, built in the 1920s, completed the supply of houses already built in previous years ( 57 blocks of flats housing 483 families). The village project included "a school building, a gym, a church, bathrooms and showers, washhouses, an ambulance, grocery and general goods stores", as well as "vegetable gardens." The houses were small and made up of "two flats, with one, two or more bedrooms respectively", making a total of "around forty blocks of flats, with over 70 detached houses grouped together and around 1,000 liveable rooms" (Società anonima Acciaierie e Ferriere Lombarde, Le provvidenze sociali, 6).

67. Information about the founder, Giorgio Enrico Falck, comes from the Archivio Falck (Falck Archives, hereafter AF), Minutes from the Board of Directors meetings, 15 January 1948. For information about his first son, Enrico, see the various writings collected in Falck, Scritti politici. For information about the last successor, Alberto Falck, see Il punto $\dot{e}$.

68. On the high level of labour turnover, see Suffia, "Il caso della forza" and Licini, "Operai e operaie."

69. Sudati, Tutti i dialetti, 232.

70. "Well, the ones who lived in the Falck village were all children of people who worked for Falck because at that time only women who worked for Falck could come and live there, like those, there was the Breda village, the Marelli village, each large company had this village ... Falck to put its employees, some of its employees, because Falck had one in Brugherio too, a Falck village, not just there, well, it had a village in Arcore for the factory workers;" "Raccolta di testimonianze operaie sulle dismissioni delle grandi fabbriche a Sesto San Giovanni," available at http://www.fondazioneisec.it [Accessed 29 July 2015].

71. Le Acciaierie e Ferriere, 6.

72. Trezzi, "La convergenza," 135.

73. In the 1930s, large companies came to control almost half the rented accommodation market of Sesto San Giovanni. Abbiati and Franceschini, "Settore edilizio."

74. Sudati, Tutti i dialetti, 186-7.

75. For a discussion of the potentially paternalistic use of the houses built for the workers, i.e., their misuse as a means of worker/tenant control, see Consonni and Tonon, "La terra degli ossimori," 129-33. Nevertheless, there is a lack of specific research concerning the housing policies applied by Falck and Breda that can corroborate these theories. 
76. With regard to the precarious housing conditions, especially for those who were not employed by large companies, see Sudati, Tutti $i$ dialetti, 189-210.

77. In 1960, Falck managed 7257 rooms. For a report on building by Falck for its own workers, see "1 vano ogni 2 dipendenti," La Ferriera (July 1960), 1-10.

78. Trezzi, "Lo sviluppo della società," 175.

79. AF, VCA, 28 February 1924; 24 September 1935; ASM Gab. Pref., II, sc. 374, Relazione sul programma di costruzione.

80. Case per i lavoratori, La Ferriera (December 1954).

81. In addition to residences, Falck made over 100 hectares of irrigated land available to "workers' families" for the growing of "cereals and vegetables for their own consumption. They consist in approximately three hundred vegetable plots and constitute a benefit that is highly appreciated by those who use them" (Società anonima Acciaierie e Ferriere Lombarde, Le provvidenze, 6.)

82. Actions of entrepreneurs to meet the ever-growing housing demand was advocated by local authorities in the early 1920s, appealing to their "sense of civil responsibility;" see Municipality of Sesto San Giovanni, Relazione del R. Commissario, 8.

83. La Società Italiana Ernesto Breda.

84. For an examination of the low level of union conflicts found in Sesto San Giovanni in comparison with other areas with strong industrial settlement until the beginning of the 1920 s see Longoni, "La nascita e l'affermazione."

85. Nurra, "Un nuovo grande quartiere."

86. Howard, Garden Cities.

87. Sudati, Tutti i dialetti, 187-93.

88. Trezzi, "Verso una più avanzata," 96-7.

89. Regarding building activity, see Municipality of Sesto San Giovanni, Sesto San Giovanni.

90. At Ercole Marelli "the principle of order and wise organisation ... (fostered) the worker's health and prevention of accidents in the workplace;" see "L'Officina E. Marelli di Sesto San Giovanni," La Tecnica dofficina, 31 July 1912.

91. Willson, La fabbrica orologio, 158.

92. The number of women receiving assistance in the period from 1927 to 1933 was 160 , with 22,050 medicals, the distribution of powdered milk and clothing; see "L'inaugurazione del Nido Magneti Marelli," Sprazzi e bagliori 10 (1933), 54.

93. Crespi, Capitale operaia.

94. Safety at work became the cause of bitter conflicts with the unions, especially in the 1950s and 1960s. See Patanè, "Prevenzione e infortune."

95. Initially, the companies examined here limited their support to financing the school funded at the turn of the last century by "Società Operai di M.s di Sesto San Giovanni" and built proper company schools only later. Istituto per la storia dell'età contemporanea (Isec), Fondo Società di M.S. di Sesto, signature 4, Consorzio per l'insegnamento ... Scuola di disegno della Società operaia di m.s.

96. ASB, Feb., signature 971, fasc. 1935, Fondazione Ernesto Breda, Relazione e conto consuntivo anno 1931.

97. Varini, Lopera condivisa.

98. ASB, Feb., signature 831, fasc. 1763, Opere di assistenza sociale.

99. Ercole Marelli established its own vocational school which in the 1930s saw student numbers increase from 152 in 1932 to 1500 in 1939, while Magneti in 1924 established a "factoryschool" (scuola officina) for its employees which in the early 1930s had around 100 students ("In casa nostra," Sprazzi e bagliori, no. 4 (1933); "La scuola interna alla F.I.M.M. in visita alla Fiat," Sprazzi e bagliori, no. 2 (1934); "Preparazione delle maestranza," Sprazzi e bagliori, no. 4 (1941).

100. Isec, fondo Società di mutuo soccorso di Sesto San Giovanni, signature 4, fasc. 4, Notizie statistiche. Anni vari.

101. Trezzi, "Verso una più," 104.

102. Evidence collected in Ganapini, ed., “... Che tempi.” 
103. Award ceremonies were one of the most celebrated occasions for companies. See in particular the annual celebrations at Falck described in the in-house magazine La Ferriera.

104. Trezzi, "Lo sviluppo della società," 57.

105. Ibid.

106. Opera Balilla, Refezione scolastica.

107. Grazia, Consenso e cultura. For Sesto San Giovanni see Minella, "Lopera nazionale."

108. For an overview of the workers' club at Magneti Marelli see "Ventianni di lavoro alla Fabbrica italiana Magneti Marelli," Sprazzi e bagliori 1 (1937). Information for Falck in AF, Verbale assemblea dei soci (Vas), 23 April 1941, 17 April 1942. For Breda, see La società italiana Ernesto Breda.

109. Rifranti, "Una città industriale," 514-9.

110. An example can be found in Pasquale Densi, who was responsible for the workers' club at Marelli and never joined the Fascist Party, later accused of anti-Fascist activities. Similar opposition to the Fascist regime as far as the management of the enterprise was concerned could be found also at Falck, where the founder's sons were also arrested in 1943 for antiFascism; see Manzini, Una vita operaia.

111. "Glorifichiamo l'uomo." Sesto lavoratrice, 11 November 1911. Similar views were expressed at the death of Ercole Marelli as can be seen in La voce di Sesto, 2 September 1922.

112. The letters sent to the workers' club repeatedly referred to "our great company" and acknowledged "the commendable assistance given to relatives in need." See "Lettere al Dopolavoro della Ercole Martelli." Annali 2: Studi e strumenti di storia metropolitana milanese (1993), 243-56.

113. Isec, Fondo Rossinovich (Ercole Marelli), Partito Comunista Italiano ... Il lavoro del partito alla Ercole Marelli di Sesto S. G. per l'unità della classe operaia.

114. Investigations carried out by the prefecture in Milan highlighted episodes of dissent towards the decisions taken by the company management, especially during the deep economic crisis that started at the end of the 1920s. Nevertheless, these episodes were only few, mainly directed against the Fascist regime or complaints due to incidental situations. Archivio di Stato di Milano (Milan State Archives) ASM, Gabinetto di Prefettura, signatures 337, 342, 345, 357, 963, 1051, 1123.

115. "Lattività del Dopolavoro nell’anno XII," in Sprazzi e bagliori 1 (1935).

116. For Falck, see the in-house publication La Ferriera, and for Breda, Notiziario Breda.

117. Willson, La fabbrica orologio, 112, 160.

118. "Workers and production managers are considered to be responsible for the good quality of the production ... due to their experience and the competence they have acquired," (Vannucci, "La qualità nella produzione," 29).

119. Varini, Lopera condivisa, 130-1; Viani, "Il lavoro operaio."

120. In Sesto San Giovanni, Falck was divided into four plants, according to the different production lines called Unione, Concordia, Vittoria and Vulcano.

121. Manzini, Una vita operaia, 21.

122. AF, from the records of the Board of Directors' meetings, February 1947.

123. Manzini, Una vita operaia.

124. For the industrial organisation of post-war production see Varini, Lopera condivisa, and for specific referements to the ERP see Varini, "Technology and Productivity."

125. Information on union disputes during the post-war years see Vimercati, "Storia sindacale;" Cingoli, "Fra cogestione;” Pozzobon, Mari, "Le Afl Falck;" Ganapini, Una città, la guerra.

126. In the reconstruction years, Breda saw a strong personnel reduction, from 15,872 in 1949 to 8,733 in 1952 (Varini, Lopera condivisa).

127. Trezzi, "Verso una più avanzata frontiera," 81-4.

128. See various references contained in the minutes of the Board of Directors' meetings held at Falck during the 1950s and even more so with the occurrence of the economic crisis at the start of the 1960s. AF, Minutes of the Board of Directors' meetings.

129. Varini, "La metamorfosi industrial."

130. AF, Balance sheet 1963. 
131. Varini, "La metamorfosi industriale."

132. Data on the number of tenants were approximate, as company sources did not always distinguish between the various factories located throughout Italy.

133. Varini, "Un welfare composito," 121-69.

134. Over the years the whole system of companies was transferred to the town council; in particular the sports and recreational facilities were taken over by associations in the private sector or institutions in the public sector (ibid.).

135. Many photographs of these ceremonies appeared in the company's in-house magazine $\mathrm{La}$ Ferriera during the years under consideration.

136. “Corsi speciali di addestramento sulle relazioni umane nell'impresa," La Ferriera (December 1954), 8.

137. "The company is an organism that takes the form of a human community ... for which everyone assumes a responsibility, precisely so that this community can fulfil a purpose that transcends that of the company"; "Concluso con successo a Sesto il corso unico UCID per i capi maestranza," La ferriera (November 1960), 11.

138. On the Falck dynasty, see James, Family Capitalism.

139. Concerning the "scientific" management of the welfare initiatives at Magneti Marelli, see Bigazzi, "Le permanenze del paternalismo," 50.

140. "We, however, concern ourselves, what is more, with endearing him to and having him play an active role in our organisation through appropriate social assistance measures ... not as empty philanthropy, nor as empty charity, but as a means of improving the worker's performance;" Quintavalle, "Le possibilità," 7.

141. Benni, "Lassistenza ai lavoratori," 43; Benni oltre alla carica di amministratore, fu negli anni Trenta presidente della Confindustria e Ministro delle Comunicazioni (Cannistraro, "Benni," 67).

142. Sprazzi e bagliori 7 (1927), 11; for a more in-depth analysis see Willson, "The Golden Factory."

143. "Our big Marelli family ... I know that our Marelli organised, with his traditional magnanimity, a commendable service of assistance for the needy families of those called to service in the armed forces and that many families already periodically receive aid and benefits" (Guerrini and Pluviano, "La nostra bella," 248).

144. For an interesting comparison, see Yacob, "Model of Welfare Capitalism?", where the author affirms: "the paternalistic practices of welfare capitalism ... were mutually complementary to both employers and employees" (ibid., 139).

145. The compliance "is a more useful conceptual tool in explaining the welfare contract between capital and labour than the model of industrial paternalism" (Barry and Melling, "The Problem of Culture," 18).

146. For a perspective on this collaboration, see Hecksher and Adler, The Firm as Collaborative.

147. Bigazzi, "Le permanenze del paternalismo," 63.

148. Scranton, Endless Novelty; Scranton, "Varieties of Paternalism," 235-57.

149. The evidence collected from factory representatives at Magneti Marelli contained repeated references to "solidarity and ... mutual respect among co-workers, moral support and teaching." This is significant as it confirms the importance of shared values. Professional capabilities were the basis of relationships at work, which were comparable to those of a large family; see Ganapini, ed., “... che tempi”.

150. On the growth of the Welfare State in Italy, see Battilani and Fauri, Consumare il Welfare.

\section{Notes on contributor}

Valerio Varini holds a $\mathrm{PhD}$ in Economic and Social History and works as an assistant professor in Economic and Business history at the Department of Economics, Management and Statistics, University of Milano, Bicocca, Italy. His research interests deal with Business history in Italy during the nineteenth and twentieth centuries, focusing on the welfare company. His current research projects deals with the transformation of private and public welfare institutions, as well as with the decline of the big companies in Italy after the Second World War; special research interest includes 
the history of entrepreneurship in the public utilities during twentieth century in the Lombardy urban cities. Currently, he is working on the history of the electric 'mini mills' in the Italian steel industry.

\section{Bibliography}

"Patronage, Paternalism, and Company Welfare." Special issue. International Labour and WorkingClass History 53 (Spring 1998).

“The Company Towns in Italia." Special issue. Annali di storia dell'impresa 13 (2002).

Abbiati, Paolo, and Bruno Franceschini. "Settore edilizio e sviluppo urbano a Sesto San Giovanni dal 1916 al 1936." Dissertation, Politecnico di Milano, 1982/3.

Alasia, Franco. La vita di prima. Milan: Jaca Book, 1984.

Amatori, Franco. "Entrepreneurial Typologies in the History of Industrial Italy: Reconsiderations." Business History Review (Spring 2011): 151-180.

Amatori, Franco, and Andrea Colli, eds. Comunità di imprese. Sistemi locali in Italia tra Ottocento e Novecento. Bologna: Il Mulino, 2001.

Barry, Jonathan, and Joseph Melling. "The Problem of Culture: An Introduction.” In Culture in History. Production, Consumption and Values in Historical Perspective, edited by Joseph Melling and Jonathan Barry, 5-21. Exeter: University of Exeter Press, 1992.

Battilani, Patrizia, and Francesca Fauri, eds. Consumare il Welfare. L'esperienza italiana del secondo Novecento. Bologna: Il Mulino, 2013.

Benenati, Elisabetta. "Cento anni di paternalismo aziendale." In Tra fabbrica e società. Mondi operai del Novecento, edited by Stefano Musso, 43-82. Milan: Feltrinelli, 1999.

Benni, Antonio Stefano. "Lassistenza ai lavoratori." Lassistenza sociale nell'industria 3 (1931): 43.

Berta, Giuseppe. “Torino: una company town? Alcune considerazioni." Annali di storia dell'impresa 13 (2002): 9-22.

Bigazzi, Duccio. "Le permanenze del paternalismo: Le politiche sociali degli imprenditori in Italia tra Ottocento e Novecento." In Ricerche di storia in onore di Franco Della Peruta, edited by Maria Luisa Betri and Duccio Bigazzi, 36-63. Milan: Franco Angeli, 1994.

Bonelli, Franco, ed. Acciaio per l'industrializzazione. Contributi allo studio del problema siderurgico italiano. Turin: Einaudi, 1982.

Bonin, Huber. "Issues Concerning the Stages of Paternalism." In Old Paternalism, New Paternalism, Post Paternalism (19th-21st Centuries), edited by Huber Bonin and Paul Thomes, 11-30. Brussels: Peter Lang, 2013.

Bonin, Huber, and Paul Thomeseds eds. Old Paternalism, New Paternalism, Post Paternalism (19th21th Centuries). Brussels: Peter Lang, 2013.

Borges, Marcelo J., and Susana B. Torres, eds. Company Towns. Labor, Space, and Power Relations across Time and Continents. New York: Palgrave Macmillan, 2012.

Cannistraro, Philip V. "Benni Antonio Stefano." In Historical Dictionary of Fascist Italy, 40-48. Westport, CT: Greenwood Press, 1982.

Carera, Aldo. I confini dello sviluppo. La regione economica lombarda come questione storiografica. Milan: Vita e Pensiero, 2000.

Carera, Aldo, ed. Opere sociali e responsabilità d'impresa: Casi e temi nel Novecento. Milan: Vita e Pensiero, 2009.

Carreras, Albert. "Un ritratto quantitativo dell'industria italiana." In Storia d'Italia, Annali 15 (1999): 181-252.

Cenciarini, Renzo A., and Stefania Licini. Magneti Marelli la storia e la business transformation. Milan: Giuffrè Editore, 1996.

Cingoli, Lorenza. "Fra cogestione e conflitto: Lattività degli organismi di fabbrica alla Breda dal 1945 al 1947." Annali 3, Studi e strumenti di storia contemporanea 3 (1994): 545-576.

Ciuffetti, Augusto. "I villaggi di miniera della Montecatini nell'Italia centrale (1919-1943): modelli insediativi e tipologie edilizie." In Sopra l'Inferno. Il villaggio di Miniera di Perticara, edited by Girolamo Allegretti and Ercole Sori, 112-137. Montefeltro: Società di studi storici per il Montefeltro, 2003. 
Ciuffetti, Augusto. Casa e lavoro: Dal paternalismo aziendale alle "comunità globali": Villaggi e quartieri operai in Italia tra Otto e Novecento. Perugia: Crace, 2004.

Ciuffetti, Augusto. La città industriale. Un percorso storiografico. Perugia: Crace, 2004.

Ciuffetti, Augusto. "Le colonie marine dallo Stato sociale fascista al 'miracolo economico"' Special issue, Patrimonio industriale, nos 9-10 (2012): 14-20.

Ciuffetti, Augusto, and Roberto Parisi, eds. Larcheologia industriale in Italia. Storie e storiografia (1978-2008). Milan: Franco Angeli, 2012.

Colli, Andrea. "Cent'anni di "grandi imprese." In La Lombardia. Storia d'Italia. Le regioni dall'Unità a oggi. Turin: Einaudi, 2001: 481-530.

Consonni, Giancarlo, and Graziella Tonon. "La terra degli ossimori." In Storia d'Italia: Le regioni dall'unità ad oggi: La Lombardia, 53-190. Turin: Einaudi, 2001.

Crawford, Margaret. Building the Workingman's Paradise: The Design of American Company Towns. London: Verso, 1995.

Crespi, Pietro. Capitale operaia: Storie di vita raccolte tra le fabbriche di Sesto San Giovanni. Milan: Jaca Book, 1979.

Darley, Gillian. Villages of Vision: A Study of Strange Utopias. Nottingham: Five Leaves Publ, 2007.

Davis, Horace. “Company Towns." In Encyclopedia of Social Sciences, 412-418, vol. 4. New York: Macmillan, 1937.

De Grazia, Victoria. Consenso e cultura di massa nell'Italia fascista: L’organizzazione del lavoro. RomaBari: Laterza, 1981.

Doty, Robert. "The Italian Detroit." New York Times 17 February 1968.

Falck, Enrico. Scritti politici e sociali. Milan: Ambrosianeum, 1955.

Fiorillo, Silvio. "Il villaggio Falck: Architettura e note storiche." Quaderni del Museo dell'Industria e del Lavoro 1 (April 2002): 115-137.

Fontana, Giovanni Luigi, ed. Le vie dell'industrializzazione. Bologna: Il Mulino, 1997.

Fontana, Giovanni Luigi. "Dar casa agli operai. Logiche d'impresa e ingegneria sociale nell'indusrializzazione moderna." Quaderni della Fondazione Dalmine (2003): 13-64.

Fontana, Giovanni Luigi. "Formazione ed evoluzione di una città de lavoro: Schio, 'Nuova Schio' e l'industria Laniera." In "I villaggi operai." Special issue. Ricerche Storiche, edited by Angelo Nesti, 47-88, 1, 2009.

Frey, Jean-Pierre. Le ville industrielle e ses urbanités: La distinction ouvrieres-employés, Le Creusot, 1870-1930. Liège: Mordaga, 1986.

Fridenson, Patrick. "Business History and History." In The Oxford Handbook of Business History, edited by Geoffrey Jones and Jonathan Zeitlin, 9-36. Oxford: Oxford University Press, 2008.

Frumento, Armando. Imprese lombarde nella storia dell siderurgia italiana. Il contributo dei Falck, 1883-1913. Milan: Allegtretti, 1952.

Ganapini, Luigi, ed. “... Che tempi, però erano bei tempi ...”: La commissione interna della Magneti Marelli nella memoria dei suoi protagonisti. Milan: Franco Angeli, 1986.

Ganapini, Luigi. Una città, la guerra. Lotte di classe, ideologie e forze politiche a Milano, 1939-1951. Milan: Franco Angeli, 1988.

Garner, John ed. The Company Town: Architecture and Society in the Early Industrial Age. Oxford: Oxford University Press, 1992.

Garner, John. "Company Towns." In Encyclopedia of Urban America: The Cities and Suburbs, edited by Neil Shumsky, 142-146, vol. 1. Santa Barbara, CA: ABC - Clio, 1998.

Greco, Sabrina, ed. Costruzione e trasformazione del paesaggio: la città industriale di Sesto San Giovanni. Milan: CLUP, 2002.

Guerrini, Irene, and Marco Pluviano, eds. “'La nostra bella e grande famiglia.' Lettere al dopolavoro della Ercole Marelli." Annali 2. Studi e strumenti di storia metropolitana milanese (1993).

Gueslin, André. "Le Paternalisme 'rivisitê" en Europe occidentale." Genéses 7 (1992): 201-211.

Guiotto, Luigi. La fabbrica totale: Paternalismo industriale e città sociali in Italia. Milan: Feltrinelli, 1979.

Hecksher, Charles, and Paul Adler, eds. The Firm as Collaborative Community: Reconstructing Trust in the Knowledge Economy. Oxford: Oxford University Press, 2006. 
Howard, Ebenezer. Garden Cities of To-Morrow. Being a Second edition of To-Morrow. A Peaceful Path to Real Reform. London: Faber and Faber, 1902.

Il punto è la responsabilità sociale. Milan: 2009.

Jacoby, Sanford M., and Modern Manners. Welfare Capitalism since the New Deal. Princeton, N.J.: Princeton University Press, 1997.

Joyce, Patrick. "Labour, Capital and Compromise: a Response to Richard Price." Social History 9 (1984): 66-77.

Joyce, Patrick. "Languages of Reciprocity and Conflict: a Further Response to Richard Price." Social History 2 (May 1984): 225-233.

La Breda. Dalla Società Italiana Ernesto Breda alla Finanziaria Ernesto Breda 1886-1986. Milan: Amilcare Pizzi Editore, 1986.

La Società Italiana Ernesto Breda per Costruzioni Meccaniche: Dalle sue origini ad oggi, 1886-1936. Verona: Mondadori, 1936.

Le Acciaierie e Ferriere Lombarde nei loro stabilimenti ed impianti. Milan: 1926.

Licini, Stefania. "Operai e operaie del gruppo Marelli: composizione mobilità della forza lavoro." In Registri del personale classe operaia italiana, edited by Ilaria Suffia, 161-180. Milan: Guerini e Associati, 2010.

Longoni, Giuseppe M. “La nascita e l'affermazione del movimento sindacale." In Sesto San Giovanni 1880-1922: Economia e società: La trasformazione, edited by Luigi Trezzi, 185-219. Milan: Skira, 1997.

Mandel, Nikki. The Corporation as Family: The Gendering of Corporate Welfare, 1890-1930. Chapel Hill: University of North Carolina Press, 2002.

Manzini, Giorgio. Una vita operaia. Turin: Einaudi, 1976.

Martinelli, Nicola. "Le politiche sociali d'impresa tra continuità e cambiamento: la Dalmine (19451950)." Bollettino dell'archivio per la storia del movimento sociale cattolico in Italia, no. 3, (2005).

Melling, Joseph. "The Company Town: Architecture and Society in the Early Industrial Age." The Business History Review 67, no. 4 (Winter 1993): 685-687.

Merlo, Stefano. Proletariato di fabbrica e capitalismo industriale. Il caso italiano 1880-1900. Florence: La nuova Italia, 1972.

Michela, Minesso, ed. Welfare e minori. L'Italia nel contesto europeo del Novecento. Milan: Franco Angeli, 2011.

Minella, Paolo. "Lopera nazionale dopolavoro a Sesto." Dissertation, Università di Milano, Department of Literature and Philosophy, 1975-76.

Morin, Marco. Beretta: the World's Oldest Industrial Dynasty. Chiasso: Acquafresca editrice, 1980.

Municipality of Sesto San Giovanni. Sesto san Giovanni ieri oggi domani. 14 anni di attività 1945-1960. Sesto San Giovanni.

Municipality of Sesto San Giovanni. Relazione del R. Commissario straordinario Avv. Comm. Giovanni Cairo al ricostituito Consiglio del Comune. Milan: 1923.

Musso, Stefano. Gli operai nella storiografia contemporanea. Rapporti di lavoro e relazioni sociali. In Tra fabbrica e società, edited by Stefano Musso. Milan: Feltrinelli, 1999.

Musso, Stefano, ed. Tra fabbrica e società. Mondi operai del Novecento. Milan: Feltrinelli, 1999.

Nesti, Angelo, ed. I villaggi operai. Special issue. Ricerche Storiche 1 (2009).

Nurra, P. "Un nuovo grande quartiere a Milano nella zona compresa tra Milano e Sesto san Giovanni." Le case popolari e le città giardino 6 (1910): 27.

Opera Balilla. Refezione scolastica, norme e considerazioni. Milan: 1937

Patanè, Paolo. "Prevenzione e infortuni tra paternalismo e repressione: Il caso della Falck negli anni Cinquanta." Annali 5, Studi e strumenti di storia contemporanea (2000): 181-210.

Pavese, Claudio. "I caratteri originali dell'insediamento: un tentativo di analisi comparata." In Sesto San Giovanni 1880-1921. Economia e società: la trasformazione, edited by Luigi Trezzi, 129-148. Milan: Skira, 1997.

Petrillo, Gianfranco, ed. La città delle fabbriche, Sesto san Giovanni 1880-1945. Milan: Franco Angeli, 1981.

Pozzobon, Marino, and Roberto Mari. "Le Afl Falck nella ricostruzione." In La ricostruzione nella grande industria, 347-381. Bari: De Donati, 1978. 
Price, Richard. “The Labour Process and Labour History”. Social History 1 (January 1983): 57-75.

Price, Richard. "Conflict and Co-operation: a Reply to Patrick Joyce." Social History 9, no. 2 (May 1984): 217-224.

Quintavalle, Umberto. "Le possibilità pratiche di organizzazione scientifica del lavoro in Italia." Sprazzi e bagliori 5 (1927): 23-26.

Quintavalle, Umberto. “Gli aspetti nazionali dell’organizzazione scientifica del lavoro.” Realtà 3 (1928): 238.

Raspadori, Paolo. "Le opere sociali della Terni: la parabola di una fabbrica totale (1884-1968)." In Comunità di lavoro. Le opere sociali delle imprese e degli imprenditori tra Otto e Novecento, edited by Luigi Trezzi and Valerio Varini, 177-208. Milan: Guerini e Associati, 2012.

Rifranti, Vittorio. "Una città industriale nella guerra: alimentazione, condizioni vita e lavoro a Sesto San Giovanni 1940-1943.” Annali 4, Studi e strumenti di storia contemporanea (1995): 489-542.

Sapelli, Giulio. Organizzazione del lavoro e innovazioni industriale nell'Italia tra le due guerre. Turin: Rosemberg \& Sellier, 1978.

Sapelli, Giulio. Perché esistono le imprese e come sono fatte. Milan: Bruno Mondadori, 1999.

Schneider, Dominique, Caroline Mathieu, and Bernard Clément, eds. Les Schneider, le Creusot: une famille, une entreprise, une ville: 1860-1960. Paris: Éditions Fayard, 1995.

Scranton, Philip. "Varieties of Paternalism: Industrial Structures and the Social Relations of production in American Textiles." American Quarterly 36 (1984): 235-257.

Scranton, Philip. Endless Novelty. Special Production and American Industrialization, 1865-1925. Princeton: Princeton University Press, 1997.

Sheare, J. Ronald. "Shelter from the Storm: Politics, Production, and Housing Crisis in the Ruhr Coal Fields, 1929-24." Journal of Contemporary History 34, no. 1 (1990).

Simoni, Carlo. Oltre la strada. Campione sul Garda: vita quotidiana e conflitto sociale in un villaggio operaio periferico. Brescia: Grafo, 1988.

Società anonima Acciaierie e Ferriere Lombarde, Le provvidenze sociali. Milan: 1925.

Sudati, Laura Francesca. Tutti i dialetti in un cortile: Immigrazione a Sesto San Giovanni nella prima metà del '900. Milan: Guerini e Associati, 2008.

Suffia, Ilaria. "Il caso della forza lavoro della Sezione Ferroviaria della Società Italiana E. Breda tra il 1894 e il 1951.” In Registri del personale e classe operaia italiana, edited by Ilaria Suffia, 97-124. Milano: Guerini e Associati, 2010.

Tone, Andrea. The Business of Benevolence: Industrial Paternalism in the Progressive Era. Ithaca: Cornell University Press, 1997.

Trezzi, Luigi. "La società nel primo ventennio del nuovo secolo." In Sesto San Giovanni 1880-1921; Economia e società: La trasformazione, edited by Luigi Trezzi, 149-184. Milan: Skira, 1997.

Trezzi, Luigi. “Lo sviluppo della società.” In Sesto San Giovanni 1923-1952: Economia e società: La crescita, edited by Luigi Trezzi, 145-208. Milan: Skira, 2002.

Trezzi, Luigi. "Le opere sociali nel Cotonificio Visconti di Modrone di Vaprio d'Adda." In I Visconti di Modrone. Nobiltà e modernità a Milano (secoli XIX-XX), edited by Gianpiero Fumi, 211-238. Rome-Bari: Laterza, 2004.

Trezzi, Luigi. "La convergenza verso una città industriale sino alla Grande Guerra.” In Paolo Tedeschi and Luigi Trezzi, Lopera condivisa: La città delle fabbriche: Sesto San Giovanni, 1903-1952: La società, 120-148. Milan: Franco Angeli, 2007.

Trezzi, Luigi. "Verso una più avanzata frontiera per una libertà dal bisogno." In Sesto San Giovanni 1953-1973: Economia e società: Equilibrio e mutamento, edited by Luigi Trezzi, 81-125. Milan: Skira, 2007.

Trezzi, Luigi, ed. Sesto San Giovanni alla fine del XX secolo 1974-1996. L’eredità volta al futuro. Milan: Skira, 2012.

Vannucci, R. "La qualità nella produzione." Sprazzi e bagliori 6 (1936): 27-29.

Varini, Valerio. L'opera condivisa: La città delle fabbriche: Sesto San Giovanni, 1903-1952: L'industria. Milan: Franco Angeli, 2006.

Varini, Valerio. "La metamorfosi industriale: dalla città delle fabbriche all'impresa diffusa." In Sesto San Giovanni 1953-1973. Economia e società: equilibrio e mutamento, edited by Luigi Trezzi. Milan: Skira, 2007. 
Varini, Valerio. "La genesi dell'impresa pubblica. La Breda nel secondo dopoguerra." In L'intervento dello Stato nelleconomia italiana. Continuità e cambiamenti (1922-1956), edited by Alberto Cova, 535-574. Milan: Franco Angeli, 2011.

Varini, Valerio. "Technology and Productivity. The Impact of the Marshall Plan on Italian Industry: an Empirical Study." In Novel Outlooks on the Marshall Plan. American Aid and European ReIndustrialization, edited by Francesca Fauri and Paolo Tedeschi, 107-132. Brussels: Peter Lang, 2011.

Varini, Valerio. "Un welfare composito. Intervento pubblico e protagonismo sociale negli anni della riconversione." In Sesto San Giovanni alla fine del XX secolo (1973-1996). L'eredità volta al futuro, edited by Luigi Trezzi, 169-216. Milan: Skira Editore, 2012.

Varini, Valerio. "The Steel Industry in a Nutshell: from Falck to the 'Mini-mills."' In The Transformation of the World Steel Industry from the Twentieth Century to the Present, edited by Charles Barhel, Ivan Kharaba and Philippe Mioche, 103-120. Brussels: Peter Lang, 2014.

Viani, Paolo. "Il lavoro operaio a Sesto San Giovanni fra tradizione e tentativi di razionalizzazione: La Breda dal 1934 al 1951.” Annali 3, Studi e strumenti di storia contemporanea (1994): 487-544.

Villaggi operai in Italia. La Val Padana e Crespi d'Adda. Turin: Einaudi, 1981.

Vimercati, Luigi. "Storia sindacale della Ercole Marelli, 1945-1975." Imsrmo, Annali 2, Studi e strumenti di storia contemporanea 2 (1993): 381-482.

Walsh, John C., and Steven High. "Rethinking the Concept of Community." Histoire Sociale/Social History 32, no. 64 (1999): 255-273.

Willson Perry, R. "The Golden Factory": Industrial Health and Scientific Management in an Italian Engineering Firm. The Magneti Marelli in the Fascist Period." In The Social History of Occupational Health, edited by Paul Weindling, 240-257. London: Croom Helm, 1985.

Willson, Perry. La fabbrica orologio: Donne e lavoro alla Magneti Marelli nell'Italia fascista. Milan: Franco Angeli, 2003.

Yacob, Shakila. "Model of Welfare Capitalism? The United States Rubber Company in Southeast Asia, 1910-1942." Enterprise \& Society 8, no. 1 (2007): 136-174.

Zahavi, Gerald. Managers and Welfare Capitalism. The Shoeworkers and Tanners of Endicott Johnson, 1880-1950. Urbana: University of Illinois Press, 1988.

\section{Appendix I. Boarding houses}

\begin{tabular}{|c|c|c|c|c|}
\hline & Falck & Breda & Ercole Marelli & Magneti Marelli \\
\hline Refectories & & $\begin{array}{l}350 \text { beds } \\
(1920)\end{array}$ & $\begin{array}{l}\text { Workers' hostel } \\
\text { (1926) }\end{array}$ & $\begin{array}{l}\text { Canteen for workers and employ- } \\
\text { ees (1930) }\end{array}$ \\
\hline $\begin{array}{r}\text { Boarding } \\
\text { houses }\end{array}$ & $\begin{array}{l}\text { Hostel for managers, employees, } \\
\text { workers } \\
6 \text { dormitories with } 750 \text { beds } \\
(1925)\end{array}$ & $\begin{array}{l}\text { Breda } \\
\text { Hostel }\end{array}$ & $\begin{array}{l}\text { Marelli Hostel } \\
\text { (1922) }\end{array}$ & - \\
\hline
\end{tabular}

\section{Appendix II. Housing}

\begin{tabular}{|c|c|c|c|c|}
\hline & Falck & Breda & E. Marelli & M. Marelli \\
\hline $\begin{array}{c}\text { Workers' } \\
\text { houses }\end{array}$ & $\begin{array}{l}\text { Houses mainly for managers and employees; a } \\
\text { total of about } 1300 \text { flats, equal to } 3000 \text { rooms } \\
\text { (1920-50) }\end{array}$ & $\begin{array}{l}300 \text { rooms in } 26 \text { build- } \\
\text { ings }(1910) ; \\
160 \text { rooms }(1926) \text {; } \\
399 \text { flats }(1950)\end{array}$ & $\begin{array}{l}\text { Workers' } \\
\text { houses } \\
(1910-25)\end{array}$ & - \\
\hline Villages & $\begin{array}{l}\text { Falck Village, completed in the } 1930 \text { s (1000 } \\
\text { rooms); } \\
\text { Diaz Village (1939) }\end{array}$ & $\begin{array}{l}\text { Two new areas with } 300 \\
\text { lodgings (1925-6) }\end{array}$ & $\begin{array}{l}\text { Marelli Village } \\
\text { (1929) }\end{array}$ & - \\
\hline
\end{tabular}




\section{Appendix III. Social security, welfare and cultural promotion}

\begin{tabular}{|c|c|c|c|c|}
\hline & Falck & Breda & E. Marelli & M. Marelli \\
\hline $\begin{array}{l}\text { Medical } \\
\text { assistance }\end{array}$ & $\begin{array}{l}\text { Sick pay (1922); } \\
\text { company health service } \\
\text { (1933) }\end{array}$ & $\begin{array}{l}\text { Medical surgery } \\
\text { 1906; } \\
\text { land bought to build } \\
\text { a hospital } \\
\text { (1919-22); workers' } \\
\text { sickness fund } \\
\text { (1921); } \\
\text { Ernesto Breda Foun- } \\
\text { dation (1921) }\end{array}$ & $\begin{array}{l}\text { Sick pay at least since 1922; } \\
\text { doctor and surgeon availa- } \\
\text { ble at the factory (1930s) }\end{array}$ & - \\
\hline $\begin{array}{l}\text { Social } \\
\text { security }\end{array}$ & $\begin{array}{l}\text { Social-security institution } \\
\text { for workers and employees } \\
\text { (1923); } \\
\text { Goisis Widows' Foundation } \\
\text { (1930s) }\end{array}$ & $\begin{array}{l}\text { Social-security insti- } \\
\text { tution for workers } \\
\text { and employees } \\
(1906,1913)\end{array}$ & Mutual funds (1926) & $\begin{array}{l}\text { Mutual funds } \\
\text { (1926) }\end{array}$ \\
\hline $\begin{array}{l}\text { Elementary } \\
\text { schools }\end{array}$ & Elementary school (1923) & $\begin{array}{l}\text { E. Breda Foundations } \\
\text { (1921) }\end{array}$ & - & - \\
\hline $\begin{array}{l}\text { Professional } \\
\text { training }\end{array}$ & Technical school & $\begin{array}{l}\text { E. Breda Foundations } \\
\text { (1921) }\end{array}$ & $\begin{array}{l}\text { Generous financing of the } \\
\text { technical school (1919); } \\
\text { company school (1925) }\end{array}$ & - \\
\hline Sports & $\begin{array}{l}\text { AFL Falck sports group: } \\
\text { football pitches, tennis, } \\
\text { fencing, bowls, tamburello, } \\
\text { cycling, } \\
\text { target shooting, canoeing } \\
(1920)\end{array}$ & $\begin{array}{l}\text { workers' club - } \\
\text { football pitches, } \\
\text { athletics, gym (1920) }\end{array}$ & Sports group (1920) & - \\
\hline $\begin{array}{l}\text { Leisure and } \\
\text { tourism }\end{array}$ & $\begin{array}{l}\text { E. Rubini Foundation } \\
\text { (1915) }\end{array}$ & $\begin{array}{l}\text { One week paid } \\
\text { holiday (1908) }\end{array}$ & & \\
\hline $\begin{array}{l}\text { Sale of food } \\
\text { and other } \\
\text { basic items }\end{array}$ & $\begin{array}{l}\text { Food and clothing co-op } \\
\text { (1917); } \\
\text { six company stores (1944) }\end{array}$ & Co-op (1917) & $\begin{array}{l}\text { Distribution of free items to } \\
\text { families in need }\end{array}$ & $\begin{array}{l}\text { Company stores at } \\
\text { least since } 1930\end{array}$ \\
\hline $\begin{array}{l}\text { Cultural } \\
\text { activities }\end{array}$ & $\begin{array}{l}\text { Reading room and library } \\
-500 \text { seats }(1921)\end{array}$ & $\begin{array}{l}\text { Science institute } \\
\text { (1917); } \\
\text { reading room and } \\
\text { library; } \\
\text { cinema/theatre } \\
\text { - } 330 \text { seats; off-li- } \\
\text { cence (1922) }\end{array}$ & & \\
\hline $\begin{array}{l}\text { Child welfare } \\
\text { (nurseries, } \\
\text { holiday } \\
\text { camps, } \\
\text { etc.) }\end{array}$ & $\begin{array}{l}\text { Irene Rubini } \\
\text { Foundation; } \\
\text { Giovanni Devoto Associ- } \\
\quad \text { ation }\end{array}$ & $\begin{array}{l}\text { Holiday Camp in } \\
\text { Sella di Valsugana }\end{array}$ & $\begin{array}{l}\text { crèche (1933); } \\
\text { Ferdinando Quintavalle } \\
\text { Foundation for seaside } \\
\text { camps in Loano and } \\
\text { Canonica d'Adda }\end{array}$ & $\begin{array}{l}\text { Land concession to } \\
\text { build camps and } \\
\text { medical services } \\
\text { (1924); } \\
\text { nursery (1933); } \\
\text { sea and mountain } \\
\text { holiday camps }\end{array}$ \\
\hline
\end{tabular}

Sources: Varini, L'opera condivisa; Tedeschi and Trezzi, L'opera condivisa; Willson, La fabbrica orologio; Sudati, Tutti i dialetti in un cortile. This list aims to give an overview of the welfare situation in Sesto San Giovanni, and is by no means exhaustive. In parentheses, year of reference or start of service. 